$$
\text { NASA-TM-81597 }
$$

NASA Technical Memorandum 81597

\title{
Superhybrid Composite Blade Impact Studies
}

C. C. Chamis, R. F. Lark, and J. H. Sinclair Lewis Research Center Cleveland, Ohio

Prepared for the Twenty-sixth Annual International Gas Turbine Conference sponsored by the American Society of Mechanical Engineers Houston, Texas, March 9-12, 1981

\section{N/SN}




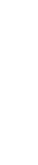

.

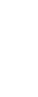




\section{DISFLAY 1B/C/1 \\ 81N11412*\# ISSUE 2 FAGE 210 CATEGOFY 37 FFTH: NASA-TM-81597 E-580 \\ 80/00/00 IO FAGES UNCLASSIFIED DOCUMENT}

UTTL: Superhybrid compasite blade impert studies

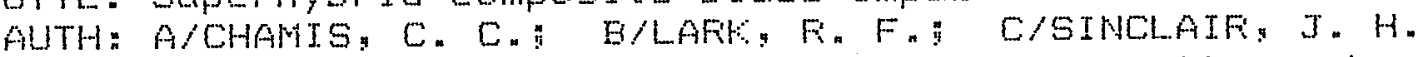

COFF: National Aeronautics and Space Administration. Lewie Fesearch Center? Cleveland, onio. AVALL.NTIS

SAF" HC AOENF AOI

CIO: UNITED STATES Fropased for presentation at the eoth Ann. Intern. Gas Turbine Conf. "Haustang Tex. 9-1. Mar. 1981

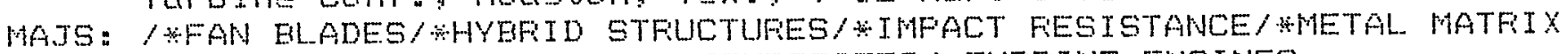
CONFOSITES/ KFESTN MATRIX COMFOSITES/ XTUREINE ENGINES

MINS: ' ALUNINUM, BOFON FEINFOFCED MATEFIALS/ CAFBON FIBEFS/ COMFOSITE MATEFIALS I FINTTE ELEMENT METHOD' STRESS ANALYSIS/ TITANTUN

ABA: A.F.H.

ABS: The feasibility of superhybrid compasite blades for meeting the mechanical design and impact resistance requirements of large fan blades for aircraft burbine engine applications was investigated. Two design concepts were evaluated: leading edge spar (TjCom) and center spar (TiCare), both with superhybrid compasite she11s. The investigation was bath enalytical and experimental. The resuls abtained shaw pramies that superhybrid composites can be used to mele light weight high quality large fan blades with good structural integrity. The blades tested succeserully ENTEF:

$4 \mathrm{~B}$ !

MOFE 


\section{SUMMARY}

An investigation was conducted to determine the feasibility of superhybrid composite blades for meeting the mechanical design and impact resistance requirements of large fan blades tor aircraft tur bine engine applications. Two design concepts were evaluated: (1) leading edge spar ( $\mathrm{TiCom}$ ) and (2) center spar ( $T i C o r e$ ), both with superhybrid com posite shells. The investigation was both analyti$c$ al and experimental. The results obtained show promise that superhybrid composites can be used to make light-weight, high-quality, large fan blades with good structural integrity. The blades tested successfully demonstrated their ability to meet steady-state operating conditions, overspeed, and small bird impact requirements.

\section{IN TRODUCTI ION}

The superhybrid composite (SHC) concept provides one means for efficiently utilizing advanced materials in certain aerospace applications. The concept combines the best characteristics of a fiber/resin matrix composite, fiber/metal matrix composite and high strength metallic foils in a single adhesively-bonded laminate. A SHC is typically made by using titanium foil as outer plies over boron/aluminum plies and an inner core of graphite fiber/epoxy plies. All these materials are adhesively bonded using a themosetting adhesive and a controlled bonding process. The result is a composite (laminate) with: (1) light weight comparable to glass fiber composites, (2) impact resistance approaching that of titanium on an impact- resistance-to-density ratio, (3) moisture and erosion resistance comparable to titanium, (4) longitudinal strength comparable to advanced fiber/resin composites, (5) transverse flexural strength comparable to titanium yield strength, and ( 6 ) bending and corsional stiffness comparable to boron/aluminum composite.

The fabrication feasibility and preliminary characterization of SHC using laboratory-type specimens are discussed in references 1 and 2. Evaluation of the SHC mechanical properties and resistance to thermal fatigue are described in reference 3 . The impact resistance of SHC using double wedge (blade-simulacion) specimens was extensively evalwated in a contractual investigation under NASA Lewis Research Center sponsorship (ref. 4). Based on the promising results obtained in the aforementioned programs, an investigation was conducted by the Aircraft Engine Group of the General Electric Company under contract to NASA Lewis Research Center to evaluate the feasibility of using SHCs in large fan blades used in aircraft engines for commercial jets (ref. 5). The objective of this report is to summarize the results obtained by the General Electric Co. investigation with emphasis on mechanical design and impact resistance aspects.

\section{BASELINE BLADE DESIGN}

A CF6-type-blade was selected as the configuration to demonstrate the feasibility of the superhybrid material concept in this program. This blade configuration met all the requirements necessary to demonstrate the superhybrid concept for use in large fan blades and to assess any benefits associated with weight, containment, and FOD resistance. Other benefits associated with the CF6 fan blade selection were: (1) It is representative of blades used in other large, high-bypass engines similar to the General Electric CF6. (2) It is a high-tip-speed $[1500 \mathrm{ft} / \mathrm{sec}(457.2 \mathrm{~m} / \mathrm{sec})]$ configuration currently in comercial service. (3) The CF 6 type aerodynamic design is being used in other composite blade pro- 
grams, including the Air Force F 103 engine graphitehybrid fan blade and a CF 6 boron/aluminum fan

blade. (4) Titanium CF 6 blades were readily available for use in machining titanium spars for this program. (5) Existing test rig hardware was available that woulc accept the CF6 superhybrid blade.

The titanium blade is shown in figure 1. There are 38 blades in the $C F-6$ fan rotor assembly. The blade has a 30 -inch $(0.762 \mathrm{~m})$ length, a 9.8-inch $(0.249 \mathrm{~m})$ tip chord, and a 6.5 -inch $(0.165 \mathrm{~m})$ root chord. The overall blade weight is 11.0 pounds $(5.00 \mathrm{~kg})$; this represents the baseline blade weight used for comparison with SHC blades made in this program. The aeromechanical characteristics of the titanium blade are summarized in table 1 . The airfoil geometry used for the superhybrid blade was the same as the CF6 titanium fan blade with the midspan shroud (fig. 1) removed.

Two basic blade design configurations were selected for evaluation. Both designs utilized metallic spars with full-length as-designed CF6 dovetails. The first design is a standard spar/shell design (designated TiCore). The spar is completely internal to the shell, figure 2. The second configuration evaluated has the metal spar shaped in a way to provide spar material at the leading-edge concave side where it can have a direct benefit in dissipating the local impact forces from a variety of foreign objects including birds. A schematic of the configuration for this blade ( $\mathrm{TiCom}$ ) is shown in figure 3 .

The design conditions selected for the superhybrid blades are those used for the mechanical design of the CFG titanium blade (table 1). No consideration was given, however, to blade low-cyclefatigue (LCF) behavior. The specific design conditions are: (1) Steady state operation at $4080 \mathrm{rpm}$ (100\% speed), (2) Maximum overspeed condition: $120 \%$ speed (operate for $5 \mathrm{~min}$ ), (3) Allowable stresses at $100 \%$ speed must be less than $70 \%$ of material strengths.

Two different spar sizes were evaluated for each blade type (TiCom, TiCore) in the preliminary design phase. The two spar sizes evaluated represent what are considered to be the extremes of the range of practical spar sizes. The small spar is limited by leading-edge FOD protection considerations in the outer airfoil. The large spar is limited by weight consideration payoffs over a CF 6 titanium blade. The results of the evaluation of the preliminary design phase are summarized in table 2 .

Several observations may be made concerning the results shown in table 2 . (1) The weight benefits of the spar/shell designs compared to an alltitanium blade can be substantial, especially if small spars can be employed about 3.1 pounds $(1.41 \mathrm{~kg})$ less than the shrouded blade. For a 38 blade stage this amounts to about 120 pounds weight saved per stage or about $30 \%$. (2) Frequency characteristics of all the superhybrid spar/shell blades, although similar to the all-ticanium cantilevered blade, are greatly reduced relative to a midspan-shroud-supported blade. Of particular interest is the low first torsional frequency of $150 \mathrm{~Hz}$ versus a midspan-supported titanium blade value of $426 \mathrm{~Hz}$. For a SHC blade of this size to be ae romechanically (flutter) acceptable, a first torsional frequency near the $426 \mathrm{~Hz}$ level of the shrouded titanium blade is required. To meet this torsional frequency requirement, the SHC blade design could be changed to increase the chord and thickness of the blade. The increased chord results in a reduced number of blades but increased weight for a fan stage. The net weight benefit will be about 60 pounds or about $15 \%$ per stage. (3) The steady-state centrifugal stress and sparto-shell shear stress were evaluated for each design. The maximum stress values are shown in the last three columns of table 2. All the calculated stresses are well within the design allowables shown in table 3. Under impact conditions, however, much higher stresses than those calculated will be present; consequently, considerable margin on steady-state stress is desirable at the evaluation of the preliminary design phase. Based on the results of the evaluation of the preliminary designs, the configurations with the small spars were selected for detail analysis evaluation.

\section{FINITE ELEMENT ANALYSIS}

The 3-D finite-element model used to carry out the detailed analysis consists of 306 brick elements and 504 nodes. The finite-element model was established to represent both the TiCore and $\mathrm{TiCom}$ blades in a single model. Using three elements through the thickness made it possible to represent the titanium/boron/aluminum skins, the graphite/epoxy core, and the titanium spar individually and in combination in the analysis. Figure 4 shows the finite-element model as projected on the $Y-2$ coordinate plane. The analysis included inertial stiffening effects corresponding to the $100 \%$ design speed of $4080 \mathrm{rpm}$, but did not include air loads. Such aerodynamic loading generally produces a negligible effect on blade stresses. The material properties used to generate the data for the finiteelement model are summarized in table 4. The superhybrid material used is a combination of titanium $(8 \%)$, boron/aluminum $(21 \%)$ and graphce/epoxy $(71 \%)$ by volume.

Typical results from the finite element analysis are presented in figures 5,6 , and 7 as stress contour plots. Peak stresses for both blades are summarized in table 5. The results show that blade stresses are well within the superhybrid material strengths for the TiCore and TiCom blades (table 4). The controlling stresses for the TiCore blade were generally in the superhybrid material; those for the TiCom blade in the titanium spar material. The stresses in the TiCom blade were considerbly higher than those in the TiCore blade. The higher stresses in the leading edge region of the TiCom blade are believed to be the result of modeling problems associated with the thin solid-titanium leading edge and are believed to be unrealistic levels. Since the stresses were within the material allowable limits, no attempt was made to refine the mode 1 .

In addition to steady-state stresses, finiteelement analysis was also used to determine the frequencies and mode shapes of the blades in the cantilever fixed-end condition. Table 6 sumarizes the first three frequencies for the $\mathrm{TiCore}$ and $\mathrm{TiCom}$ superhybrid blades at design speed and compares them with those of the titanium midspan shrouded blade. The results indicate that the blade frequencies for both superhybrid blades are equivalent but considerably below the shrouded metal blade. A design change would thus be required, including a change in number of blades per stage, to provide an aeromechanically acceptable design as mentioned previously. 


\section{BLADE FABRICATION}

Based on the results of the finite element analysis, TiCore and TiCom blades with small spars were fabricated for testing. Briefly, the blades were fabricated by hot pressing. The spars were machined to the desired dimensions from CF 6 titanium blades. The titanium plies and the boron aluminum plies were preformed to the specified shapes. The graphite-fiber composite plies and the adhesive plies were cut to the specified shape. The spar and the various plies were stacked in a mold and hot pressed under specified pressures and temperatures compatible with the resin and the adhesive systems.

The fabrication quality of the blades was deter mined by using destructive and non-destructive evaluation (NDE) tests. The destructive tests were also used to verify selected in situ strength properties as compared with those used in the finite element analysis. A correlation of NDE test results with the destructive test data was established. This corretation was used to assess the quality of the blades intended for testing in order to verify the design concept. Three blades for each $\mathrm{TiCore}$ and $\mathrm{TiCom}$ design were fabricated for verification testing.

\section{BLADE TESTING}

Bench Frequencies. Each of the six superhybrid test blades underwent bench frequency testing in the clamped-end cantilever condition. Table 7 presents the results of this testing for the first five $f$ requencies. These data show little scatter in frequencies of the superhybrid blades and modest improvements in stiffness over unshrouded titanium blades.

Spin Testing. The initial spin or whirligig testing consisted of conducting a 100-cycle spin test on a TiCore and a TiCom blade at $110 \%$ speed $(4488 \mathrm{rpm})$. Cyclic testing of both blades was completed successfully. No damage was found by using several through-transmission nondestruct ive test (NDT) hand scans of each blade at various cycle intervals throughout the testing. Blade temperatures during cyclic testing were held below $225^{\circ} \mathrm{F}$ $\left(107.2^{\circ} \mathrm{C}\right)$ at the tip and below $200^{\circ} \mathrm{F}\left(93.3^{\circ} \mathrm{C}\right)$ at the root. Temperature measurements were made by a combination of temperature sensitive point dots mounted to the blade and an air the mocouple in the shroud at the blade tip.

After cyclic testing, the blades were tested for impact in a whirligig test facility. Three TiCore and one TiCom blades were tested. A typical photograph of the test setup including disk, blade, and bird injector is shown in figure 8 .

Test results for all impact tests are summarized in table 8 . This summary shows that after starling impact the TiCore blade suffered minor damage, limited to disbond between the nickel plate and the wire mesh. The TiCom blade suffered considerbly more damage under starling impact: its spar separated from the shell, causing delamination over $50 \%$ of the air foil. Based on the results of this TiCom blade test, it was concluded that impact testing TiCom blades with larger bird slices would result in complete blade failure. Thus no further impact testing of TiCom blades was conducted.

As shown in table 8, three additional tests were conducted on the TiCore blades. A starling impact on TiCore blade 3 resulted in nickel-plate separation similar to the TiCore blade 1 test. In an attempt to determine whether any structural damage was done to either of the two TiCore blades 2 or 3 , the nickel-plate/wire mesh leading-edge protection was removed for further NDT evaluation. With the exception of a slight buckle in the titanium surface ply of TiCore blade 2, there was no damage to the blade after removing the leading-edge protection. With improvements in the nickel-plate adhesion or the substitution of a suitable alternative leadingedge protection system, it is believed that the nodamage starling impact requirement can be achieved with a TiCore blade design.

The nickel plate/wire mesh was stripped from TiCore blade 1. The blade was retested under starling impact to determine the degree of protection provided by the leading-edge protection system. The results of this test showed that without leadingedge protection local fracture occurred in the surface plies (fig. 9). This blade suffered local. fracture of the convex titanium/boron/aluminum layers with a $40 \mathrm{gram}$ weight loss and 15 -percent airfoil delamination.

The impact of a 9 -ounce $(0.255 \mathrm{~kg})$ slice on blade 2, which is nearly equivalent to the ingestion of a $1-1 / 2$ pound $(0.680 \mathrm{~kg})$ bird at aircraft takeoff conditions, resulted in considerable local damage and delamination, with an attendant blade weight loss of approximately 8-percent (fig. 10). Such damage is acceptable if the engine can maintain 75-percent power for 5-minutes without incurring subsequent damage which would result in engine shutdown. Also advantage can be taken of the flexibility inherent in the SHC concept to improve the impact resistance locally. This can be done, for example by varying the titanium plies.

\section{CONCLUSIONS}

The results of this investigation demonstrated that the superhybrid composite concept can be utilized to produce light weight, large fan blades. The manufacturing process developed during this program demonstrated that several prototype blades could be manufactured with good unifomity and dimensional control and that the process is capable of being scaled up for preproduction quantities of blades. Whirligig testing validated that both the $\mathrm{TiCore}$ and TiCom blade designs are adequate for steady-state and cyclic operating conditions. The TiCore blade proved to be the superior design from a bird-impact resistance standpoint. TiCore blades need some additional improvements in the bonding of the nickel-plate leading-edge protection system in order to avoid local separation during starling impacts.

Specific conclusions reached from this investigation include: (1) Both blade designs can successfully achieve steady-state operating conditions including overspeed and cyclic testing. (2) The superhybrid concept can provide considerable flexibility to make further improvements in FOD resistance locally. (3) Large-bird damage to the TiCore blade resulting in 8 -percent weight loss narrowly exceeded the desirable limit of 5-percent weight loss. However, this may be acceptable providing that: (a) rotor unbalance capability, (b) the amount and degree of secondary damage and (c) the ability of the engine to maintain $75 \%$ power are adequate. 
REFERENCES

1. Chamis, C. C., Lark, R. F. and Sullivan, T. L., "Boron/Aluminum-Graphite/Resin Advanced Fiber Composite Hybrids." Materials on the Move Proceedings of the Sixth National Technical Conference, Dayton, Ohio, October 8-10, 1979, PP. 368-385.

2. Chamis, C. C., Lark, R. F. and Sullivan, T. L., "Boron/Aluminum-Graphite/Resin Advanced Fiber Composite hybrids," NASA TND-7879, 1975.
3. Chamis, C. C., Lark, R. F. and Sullivan, T. L., "Super-Hybrid Composites-An Emerging Structural Material," NASA TMX-71836, 1975. 4. Novak, R. C., "Multi-Fiber Composites," NASA CR-135062, 1976.

5. Salemme, C. T. and Murphy, G. C., "Metal Spar/Superhybrid Shell Composite Fan Blades," NASA CR-159594, 1979. 
Table 1. CF6 Titanium Blade Aeromechanical Parameters

\begin{tabular}{|c|c|}
\hline Number of Blades & 38 \\
\hline Maximum Steady-State, rpm & 4080 \\
\hline Tip Speed, ft/sec $(\mathrm{m} / \mathrm{sec})$ & $1512(460.8)$ \\
\hline Tip Radius, in. (m) & $42.48(1.079)$ \\
\hline Tip Chord, in. (m) & $9.8(0.249)$ \\
\hline Root Chord, in. (m) & $6.43(0.163)$ \\
\hline Tip Solidity & 1.39 \\
\hline Root Solidity & 2.2 \\
\hline $\operatorname{Tip} \operatorname{Tm} / \mathrm{C}$ & 0.025 \\
\hline Root $\mathrm{Tm} / \mathrm{C}$ & 0.089 \\
\hline Tip Thickness, in. (m) & $0.245\left(6.22 \times 10^{-3}\right)$ \\
\hline Root Thickness, in. (m) & $0.57\left(0.145 \times 10^{-3}\right)$ \\
\hline Airfoil Weight, $1 \mathrm{bm}(\mathrm{kg})$ & $8.1(3.674)$ \\
\hline Blade Weight, lbm $(\mathrm{kg})$ & $10.8(4.899)$ \\
\hline Root Center Force, Ib (newtons) & $103,000(458,166)$ \\
\hline Root Center Stress, ksi $\left(\mathrm{n} / \mathrm{m}^{2}\right)$ & $37,000\left(2.551 \times 10^{8}\right)$ \\
\hline Root Area, in. ${ }^{2}\left(\mathrm{~m}^{2}\right)$ & $2.8\left(1.806 \times 10^{-3}\right)$ \\
\hline Airfoil Peak Stress, ksi $\left(\mathrm{n} / \mathrm{m}^{2}\right)$ & $67,000\left(4.619 \times 10^{8}\right)$ \\
\hline Location of Airfoil Peak Stress & Midchord Root \\
\hline Maximum Shear Stress Root, $\mathrm{ksi}\left(\mathrm{n} / \mathrm{m}^{2}\right)$ & N.A. \\
\hline IT Frequency, cps (hz) & $460(460)$ \\
\hline Material & Ti 6-4 \\
\hline
\end{tabular}


Table 2. Preliminary Blade Design Summary.

\begin{tabular}{|c|c|c|c|c|c|c|c|c|c|}
\hline \multirow[b]{2}{*}{ Design } & \multirow{2}{*}{$\begin{array}{l}\text { Blade Type } \\
\text { /Spar Size }\end{array}$} & \multirow[b]{2}{*}{$\begin{array}{l}\Delta \text { Weight, } \\
\text { lb }\left(\mathrm{kg}_{\mathrm{g}}\right)\end{array}$} & \multirow{2}{*}{\multicolumn{2}{|c|}{$\begin{array}{l}\text { Estimated } \\
\text { Bench Frequencies, Hz }\end{array}$}} & \multirow{2}{*}{\multicolumn{2}{|c|}{ Layup Angles }} & \multirow[b]{2}{*}{$\begin{array}{l}\text { Shear Stress, } \\
\text { ksi }\left(n / m^{2}\right)\end{array}$} & \multicolumn{2}{|c|}{ Centrifugal Strese } \\
\hline & & & & & & & & $\begin{array}{l}\text { Max Compression } \\
\mathrm{kBi}\left(\mathrm{n} / \mathrm{m}^{2}\right)\end{array}$ & $\begin{array}{l}\text { Max Tension, } \\
\text { koi }\left(n / m^{2}\right)\end{array}$ \\
\hline 1 & $\begin{array}{l}\text { Sma11 } \\
\text { TiCom }\end{array}$ & $-3.3(-1.498)$ & 35 & 150 & $\pm 15^{\circ}$ & $\pm 0^{\circ}, \pm 35^{\circ}$ & $0.6\left(4.136 \times 10^{6}\right)$ & $27\left(1.86 \times 10^{8}\right)$ & $30\left(2.07 \times 10^{8}\right)$ \\
\hline 2 & $\begin{array}{l}\text { Large } \\
\text { TiCom }\end{array}$ & $-2.8(-1.271)$ & 35 & 150 & $\pm 15^{\circ}$ & $\pm 0^{\circ}, \pm 35^{\circ}$ & $0.7\left(4.826 \times 10^{6}\right)$ & $29\left(2.0 \times 10^{8}\right)$ & $33\left(2.27 \times 10^{8}\right)$ \\
\hline 3 & $\begin{array}{l}\text { Small } \\
\text { TiCore }\end{array}$ & $-3.1 *(-1.407)$ & 35 & 150 & $\pm 15^{\circ}$ & $\pm 0^{\circ}, \pm 35^{\circ}$ & $0.5\left(3.447 \times 10^{6}\right)$ & $29\left(2.0 \times 10^{8}\right)$ & $25\left(1.72 \times 10^{8}\right)$ \\
\hline 4 & $\begin{array}{l}\text { Large } \\
\text { TiCore }\end{array}$ & $-2.3^{\star}(-1.044)$ & 35 & 150 & $\pm 15^{\circ}$ & $\pm 0^{\circ}, \pm 35^{\circ}$ & $0.6\left(4.136 \times 10^{6}\right)$ & $36\left(2.48 \times 10^{8}\right)$ & $32\left(2.21 \times 10^{8}\right)$ \\
\hline & $\begin{array}{l}\text { All-Titanium } \\
\text { Cantilevered }\end{array}$ & $-1.1(-0.500)$ & 22 & 152 & & & & & \\
\hline & $\begin{array}{l}\text { All-Titanium } \\
\text { Shrouded }\end{array}$ & 0 & 202 & 426 & & & & & \\
\hline
\end{tabular}

"Iacludes $0.5-16(0.226 \mathrm{~kg})$ Lead ing-Edge Protection.

Table 3. Material Allowables at $4080 \mathrm{rpm}$.

\begin{tabular}{|c|c|c|c|}
\hline & $\begin{array}{l}\text { Tensile, } \mathrm{ksi}\left(\mathrm{n} / \mathrm{m}^{2}\right) \\
0^{\circ}\end{array}$ & $\begin{array}{l}\text { Bending, } \mathrm{ksi}\left(\mathrm{n} / \mathrm{m}^{2}\right) \\
0^{\circ}\end{array}$ & Shear, ksi $\left(\mathrm{n} / \mathrm{m}^{2}\right)$ \\
\hline Titanium & --- & --- & $50\left(3.45 \times 10^{8}\right)$ \\
\hline Superhybrid & $92 \quad 16\left(1.10 \times 10^{8}\right)$ & $120 \quad 51\left(3.51 \times 10^{8}\right)$ & -- \\
\hline Spar/She11 Bond & -- & -- & $2\left(1.35 \times 10^{7}\right)$ \\
\hline
\end{tabular}


Table 4. Superhybrid Material Properties Used in Finite Element Analysis

\begin{tabular}{|c|c|c|c|c|}
\hline & $\underset{6-4}{\text { Titanium }}$ & $\begin{array}{l}\mathrm{B} / \mathrm{Al} \\
\pm 15^{\circ}\end{array}$ & $\begin{array}{c}\text { Graphitel } \\
\text { Epoxy } \\
0 \pm 35^{\circ}\end{array}$ & $\begin{array}{l}\text { Superhybrid } \\
\text { Configuration }\end{array}$ \\
\hline Through-Thickness Tensile Modulus, $\mathrm{E}_{11}-10^{6} \mathrm{psi}\left(10^{10} \mathrm{n} / \mathrm{m}^{2}\right)$ & $16.0(11.03)$ & $10.6(7.31)$ & $1.5(1.03)$ & $4.6(3.17)$ \\
\hline Chordal Tensile Modulus, $E_{22}-10^{6} \mathrm{psi}\left(10^{10} \mathrm{n} / \mathrm{m}^{2}\right)$ & $16.0(11.03)$ & $19.0(13.10)$ & $1.65(1.14)$ & $6.4(4.41)$ \\
\hline Radial Tensile Modulus, $E_{33}-10^{6} \mathrm{psi}\left(10^{10} \mathrm{n} / \mathrm{m}^{2}\right)$ & $16.0(11.03)$ & $26.0(17.92)$ & $10.6(7.31)$ & $14.3(9.86)$ \\
\hline Chordal Shear Modulus, $\mathrm{G}_{12}-10^{6} \mathrm{psi}\left(10^{10} \mathrm{n} / \mathrm{m}^{2}\right)$ & $6.2(4.27)$ & $6.0(4.13)$ & $0.7(0.483)$ & $2.3(1.59)$ \\
\hline Cross-Fiber Shear Modulus, $\mathrm{G}_{23}-10^{6} \mathrm{psi}\left(10^{10} \mathrm{n} / \mathrm{m}^{2}\right)$ & $6.2(4.27)$ & $10.1(6.96)$ & $2.35(1.62)$ & $4.3(2.96)$ \\
\hline Radial Shear Modulus, $G_{13}-10^{6} \mathrm{psi}\left(10^{10} \mathrm{n} / \mathrm{m}^{2}\right)$ & $6.2(4.27)$ & $6.0(4.13)$ & $0.7(0.483)$ & $2.3(1.59)$ \\
\hline Chordal Plane Poisson's Ratio $\left(\mathrm{M}_{12}\right)$ & 0.3 & 0.3 & 0.3 & 0.3 \\
\hline Cross-Fiber Plane Poisson's Ratio $\left(\mathrm{H}_{23}\right)$ & 0.3 & 0.34 & 0.62 & 0.54 \\
\hline Radial Plane Polsson's Ratio $\left(M_{13}\right)$ & 0.3 & 0.24 & 0.3 & 0.29 \\
\hline Density, $1 \mathrm{~b} / \mathrm{in} \cdot{ }^{3}\left(\mathrm{~kg} / \mathrm{m}^{3}\right)$ & $0.161(4456)$ & $0.10(2768)$ & $0.06(1661)$ & $0.076(2104)$ \\
\hline
\end{tabular}


Table 5. Summary of Peak Stresses for Superhybrid Composite Blades.

$(4080 \mathrm{rpm})$

\begin{tabular}{|c|c|c|c|c|c|c|c|}
\hline & \multirow{2}{*}{\multicolumn{3}{|c|}{ Ticore Blades }} & \multicolumn{4}{|c|}{ TiCom Blades } \\
\hline & & & & \multirow[b]{2}{*}{ Stress } & \multirow[b]{2}{*}{ Location } & \multicolumn{2}{|c|}{ Degign Allowables } \\
\hline & Stress & Location & $\begin{array}{l}\text { Design } \\
\text { Allowables }\end{array}$ & & & $\begin{array}{l}\text { Superhybrid } \\
\text { Material }\end{array}$ & $\begin{array}{l}\text { Titanium } \\
\text { Material }\end{array}$ \\
\hline $\begin{aligned} \text { Flatwise Tensile Stress } \sigma_{11}-\mathrm{ksi} \\
$\[ \left(10^{6} \mathrm{n} / \mathrm{m}^{2}\right) \]$\end{aligned}$ & $\begin{array}{l}1.0 \\
(6.894)\end{array}$ & $\begin{array}{l}\text { LE } 40 \% \\
\text { Span }\end{array}$ & $\begin{array}{l}3.0 \\
(20.68)\end{array}$ & $\begin{array}{l}10.0 \\
(68.95)\end{array}$ & $\begin{array}{l}\text { Root Midchord } \\
\text { Region }\end{array}$ & $\begin{array}{l}3.0 \\
(20.68)\end{array}$ & $\begin{array}{l}90^{\star \star} \\
(620.53)\end{array}$ \\
\hline 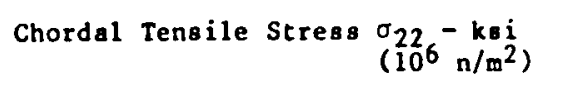 & $\begin{array}{l}5.0 \\
(34.47)\end{array}$ & $\begin{array}{l}\text { LE } 40 \% \\
\text { Span }\end{array}$ & $\begin{array}{l}22.0 \\
(151.68)\end{array}$ & $\begin{array}{l}40.0 \\
(275.79)\end{array}$ & LE $50 \pi$ Span & $\begin{array}{l}22.0 \\
(151.68)\end{array}$ & $\begin{array}{l}90^{\star \star} \\
(620.53)\end{array}$ \\
\hline $\begin{aligned} & \text { Radial Tensile Stress } \sigma_{33}-\mathrm{ksi} \\
&\left(10^{6} \mathrm{n} / \mathrm{m}^{2}\right)\end{aligned}$ & $\begin{array}{l}35.0 \\
(241.32)\end{array}$ & $\begin{array}{l}\text { Root LE } \\
\text { Region }\end{array}$ & $\begin{array}{l}70.0 \\
(482.63)\end{array}$ & $\begin{array}{l}65.0 \\
(448.16)\end{array}$ & LE Root Region & $\begin{array}{l}70.0 \\
(482.63)\end{array}$ & $\begin{array}{l}90^{\star \star} \\
(620.53)\end{array}$ \\
\hline $\begin{array}{r}\text { Chordal Shear Stress } \begin{array}{r}\sigma_{12}-\mathrm{ksi} \\
\left(10^{6} \mathrm{n} / \mathrm{m}^{2}\right)\end{array}\end{array}$ & $\begin{array}{l}0.5 \\
(3.45)\end{array}$ & $\begin{array}{l}\text { LE } 40 \% \\
\text { Span }\end{array}$ & $\begin{array}{l}5.0 \\
(34.47)\end{array}$ & $\begin{array}{l}8.0 \\
(55.16)\end{array}$ & LE $40 \pi$ Span & $\begin{array}{l}5.0 \\
(34.47)\end{array}$ & $\begin{array}{l}50^{\star \star} \\
(344.74)\end{array}$ \\
\hline $\begin{aligned} \text { Cross-Piber Shear Stress } & \sigma_{23}-\mathrm{ksi} \\
& \left(10^{6} \mathrm{n} / \mathrm{m}^{2}\right)\end{aligned}$ & $\begin{array}{l}5.0 \\
(34.47)\end{array}$ & $\begin{array}{l}\text { Midchord } \\
20 \% \text { Span }\end{array}$ & $\begin{array}{l}17.0 \\
(117.21)\end{array}$ & $\begin{array}{l}13.0 \\
(89.63)\end{array}$ & LE 40\% Span & $\begin{array}{l}17.0 \\
(117.21)\end{array}$ & $\begin{array}{l}50^{\star \star} \\
(344.74)\end{array}$ \\
\hline $\begin{aligned} \text { Radial Shear Stress } & \sigma_{13}-\mathrm{ksi} \\
& \left(10^{6} \mathrm{n} / \mathrm{m}^{2}\right)\end{aligned}$ & $\begin{array}{l}4.0 \\
(27.58)\end{array}$ & $\begin{array}{l}\text { Midchord } \\
\text { Root Region }\end{array}$ & $\begin{array}{l}8.0 \\
(55.16)\end{array}$ & $\begin{array}{l}4.0 \\
(27.58)\end{array}$ & $\begin{array}{l}\text { Midchord Root } \\
\text { Region }\end{array}$ & $\begin{array}{l}8.0 \\
(55.16)\end{array}$ & $\begin{array}{l}50^{\star \star} \\
(344.74)\end{array}$ \\
\hline
\end{tabular}

** Controlling allowable.

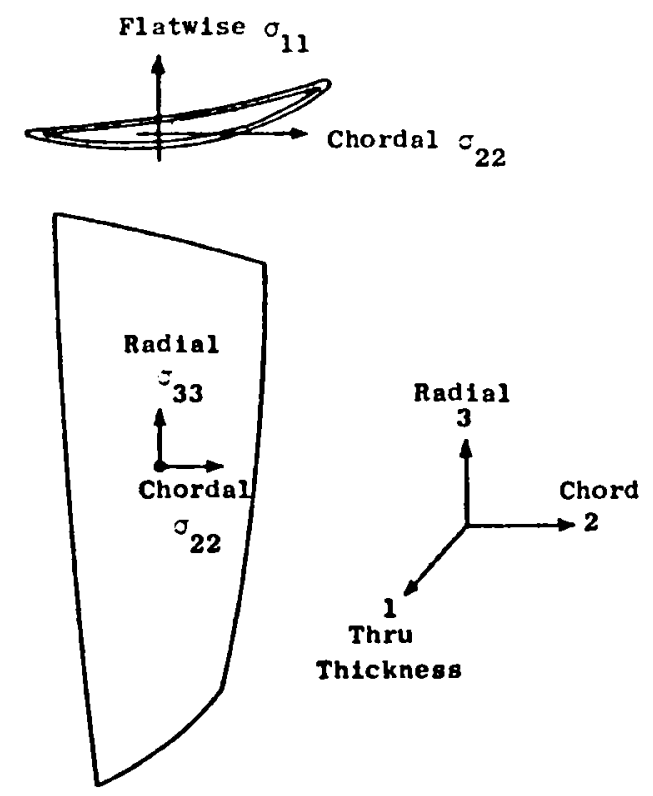


Table 6. Blade Frequencies at $4080 \mathrm{rpm}$.

\begin{tabular}{|l|c|c|c|}
\cline { 2 - 4 } \multicolumn{1}{c|}{} & \multicolumn{3}{|c|}{ Frequency, Hz } \\
\cline { 2 - 4 } & $\begin{array}{c}\text { Titanium } \\
\text { Midspan } \\
\text { Supported }\end{array}$ & \multicolumn{2}{c|}{ Superhybrid Cantilevered } \\
\cline { 2 - 4 } & 260 & 115 & 113 \\
\hline 1st Frequency (Hz) & 500 & 165 & 163 \\
2nd Frequency (Hz) & 450 & 250 & 248 \\
\hline 3rd Frequency (Hz) & & & TiCore \\
\hline
\end{tabular}

Table 7. Bench Frequencies of Superhybrid Composite Blades and CF6 Titanium Blades for Comparison

\begin{tabular}{|c|c|c|c|c|c|}
\hline \multirow{2}{*}{ Blade Type } & \multicolumn{5}{|c|}{ Cycles/second (Hz) } \\
\hline & $1 \mathrm{~F}^{*}$ & $2 \mathrm{~F}$ & $1 \mathrm{~T}^{* *}$ & $3 F$ & $4 \mathrm{~F}$ \\
\hline$\frac{\text { TiCore }}{1}$ & 30 & 92 & 186 & 230 & 442 \\
\hline 2 & 30 & 94 & 184 & 232 & 452 \\
\hline $\begin{array}{c}3 \\
\text { TiCom } \\
\end{array}$ & 30 & 94 & 184 & 232 & 446 \\
\hline 1 & 26 & 88 & 180 & 218 & 434 \\
\hline 2 & 28 & 90 & 189 & 220 & 436 \\
\hline 3 & 28 & 88 & 182 & 214 & 428 \\
\hline $\begin{array}{l}\text { CF6 Titanium Blade } \\
\text { Unshrouded } \\
\text { (cantilevered) } \\
\text { Shrouded }\end{array}$ & $\begin{array}{r}22 \\
176\end{array}$ & $\begin{array}{r}76 \\
382\end{array}$ & $\begin{array}{l}152 \\
458\end{array}$ & - & - \\
\hline
\end{tabular}

*Flexural vibration Mode

**Torsional vibration mode 
Table 8. Superhybrid Test Results.

\begin{tabular}{|c|c|c|c|}
\hline Blade Type & Slice Size & $\begin{array}{l}\text { Equivalent } \\
\text { Bird Size }\end{array}$ & Remarks \\
\hline$\frac{\text { TiCore }}{1}$ & $2.84 \mathrm{oz}(0.080 \mathrm{~kg})$ & $3.0 \mathrm{oz}(0.085 \mathrm{~kg})$ & Nickel-plate Separation \\
\hline 2 & $9.0 \mathrm{oz}(0.255 \mathrm{~kg})$ & $1.5 \mathrm{lb}(0.680 \mathrm{~kg})$ & Local Fracture \\
\hline 3 & 2.86 oz $(0.081 \mathrm{~kg})$ & $3.0 \mathrm{oz}(0.085 \mathrm{~kg})$ & Nickel-plate Separation \\
\hline $\begin{array}{l}\quad 4 \\
\text { (No Leading } \\
\text { Edge } \\
\text { Protection) }\end{array}$ & 3.0 oz $(0.085 \mathrm{~kg})$ & $3.0 \mathrm{oz}(0.085 \mathrm{~kg})$ & Local Fracture \\
\hline TiCom & & & \\
\hline 1 & $2.90 \mathrm{oz}(0.082 \mathrm{~kg})$ & $3.0 \mathrm{oz}(0.085 \mathrm{~kg})$ & Severe Delamination \\
\hline
\end{tabular}

Nominal Impact Test Conditions

Impacts at $75 \%$ Span; $3.0 \mathrm{oz}$, starling; $1.51 \mathrm{~b}$,pigeon

$3850 \mathrm{rpm}$

$23^{\circ}$ Incidence Angle

Simulates $300 \mathrm{~T} / \mathrm{Sec}\left(91.44_{\mathrm{m} / \mathrm{sec}}\right)$ Takeoff Velocity 


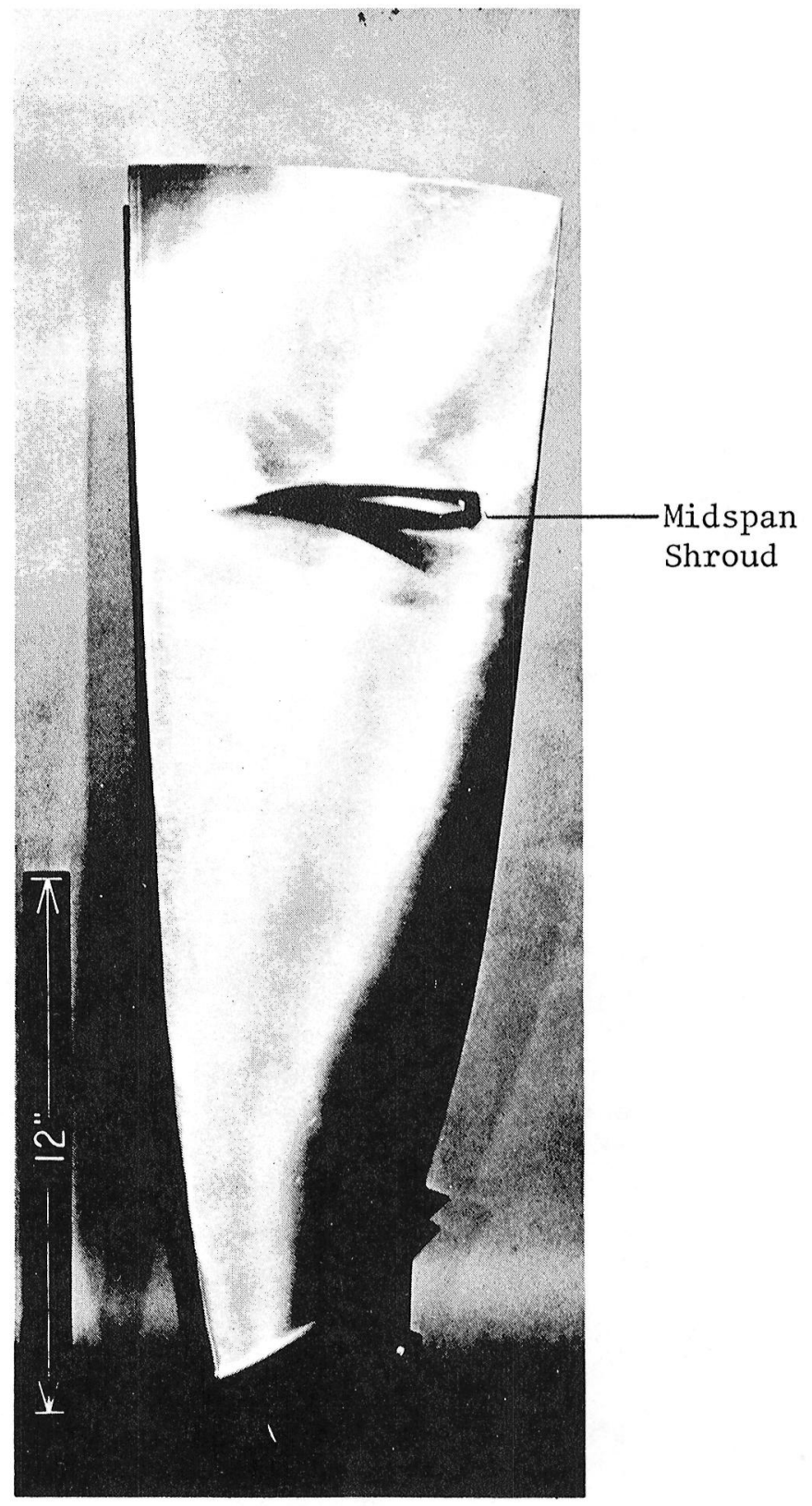

Figure 1. CF6 Titanium Blade. 

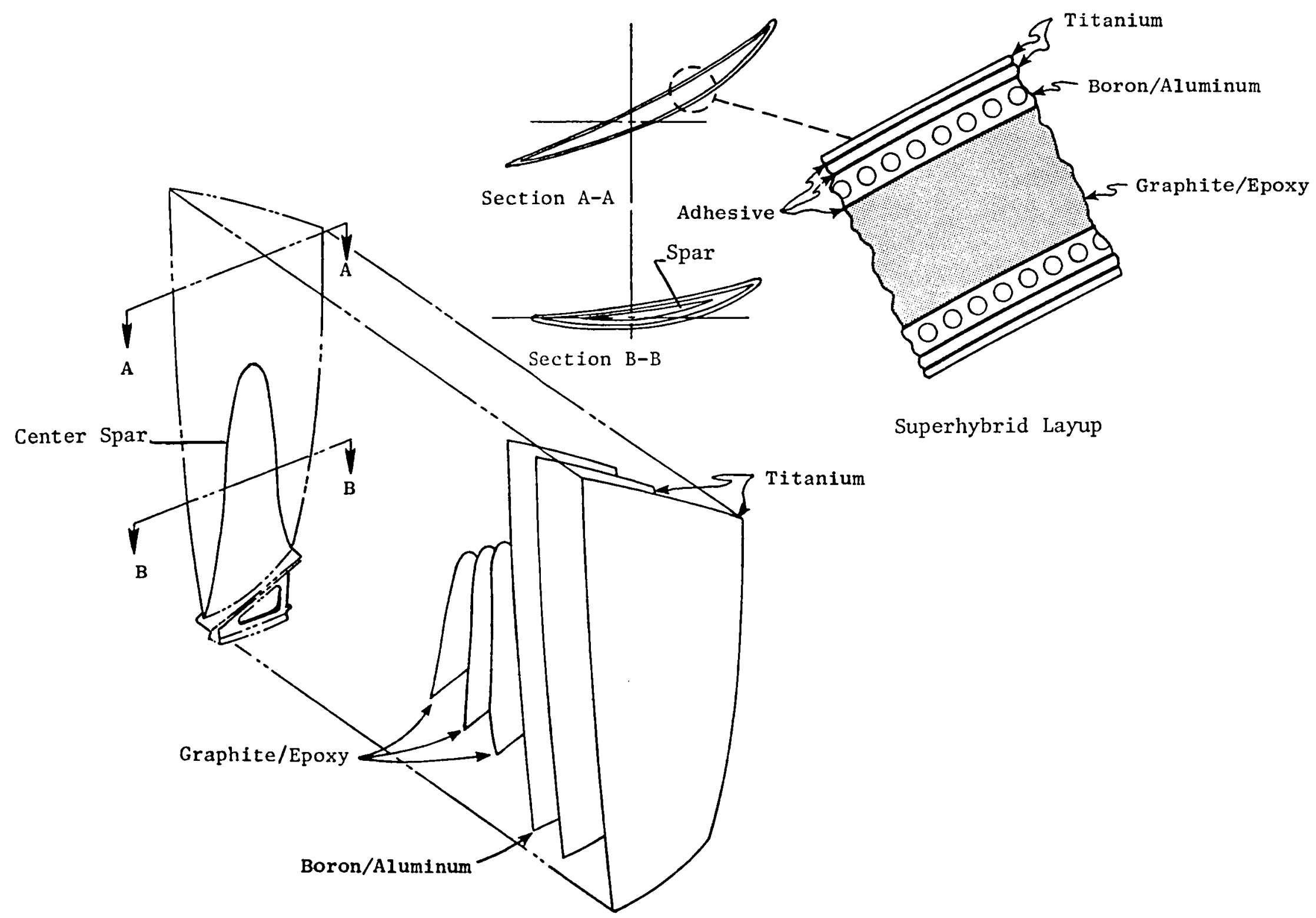

Superhybrid Layup

Figure 2. Candidate TiCore Blade Design Showing Internal Spar With Superhybrid Shell 


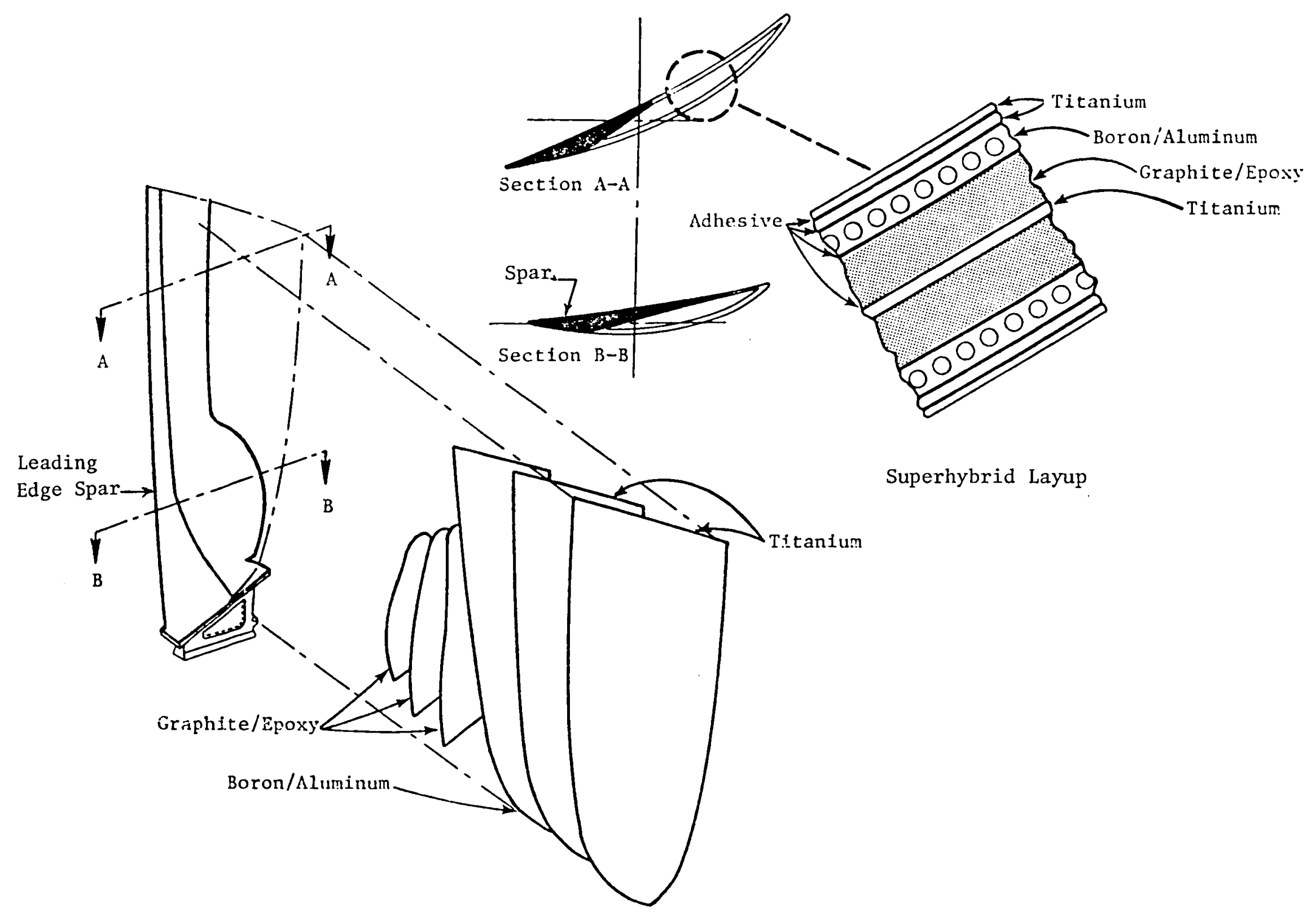

Figure 3. Candidate TiCom Blade Design Showing Leading Edge Spar with Superhybrid Shell 


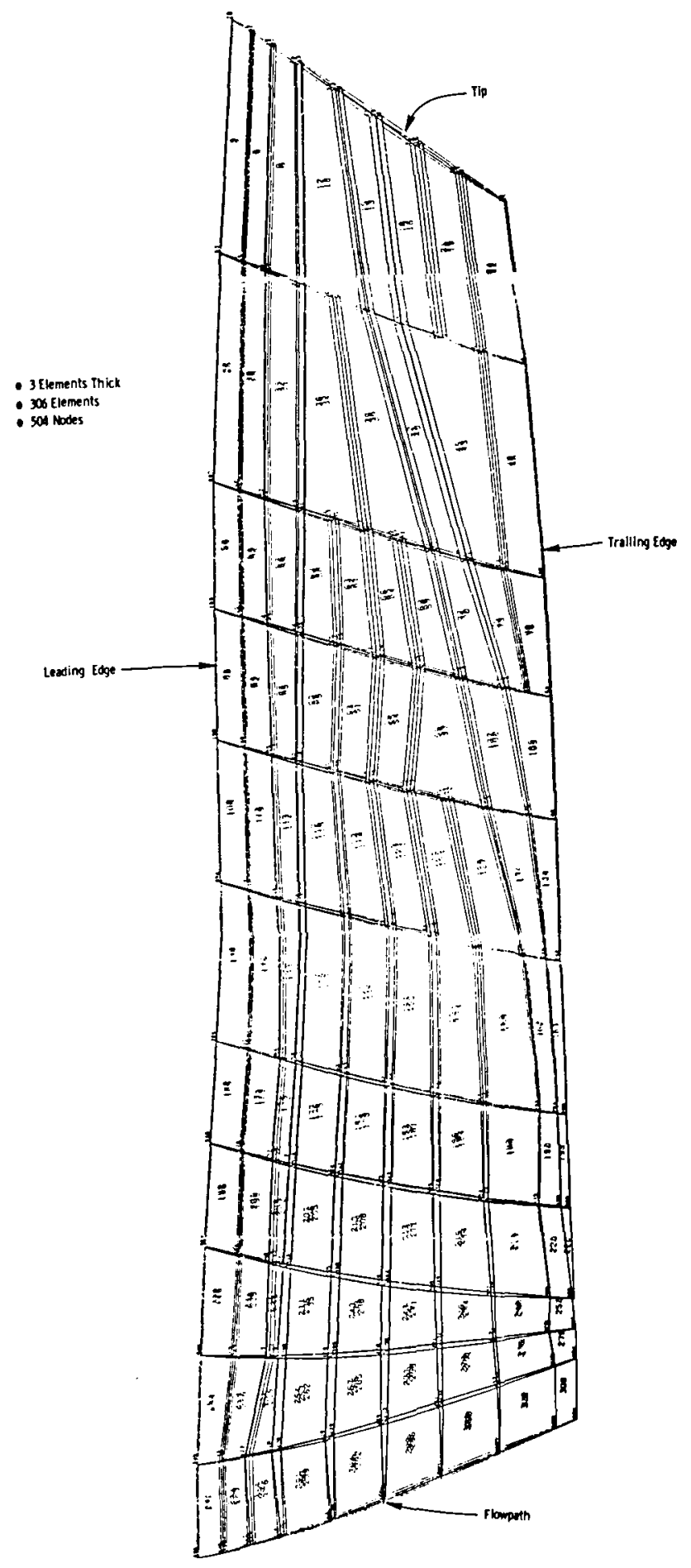

Figure 4. TAMP Model. 


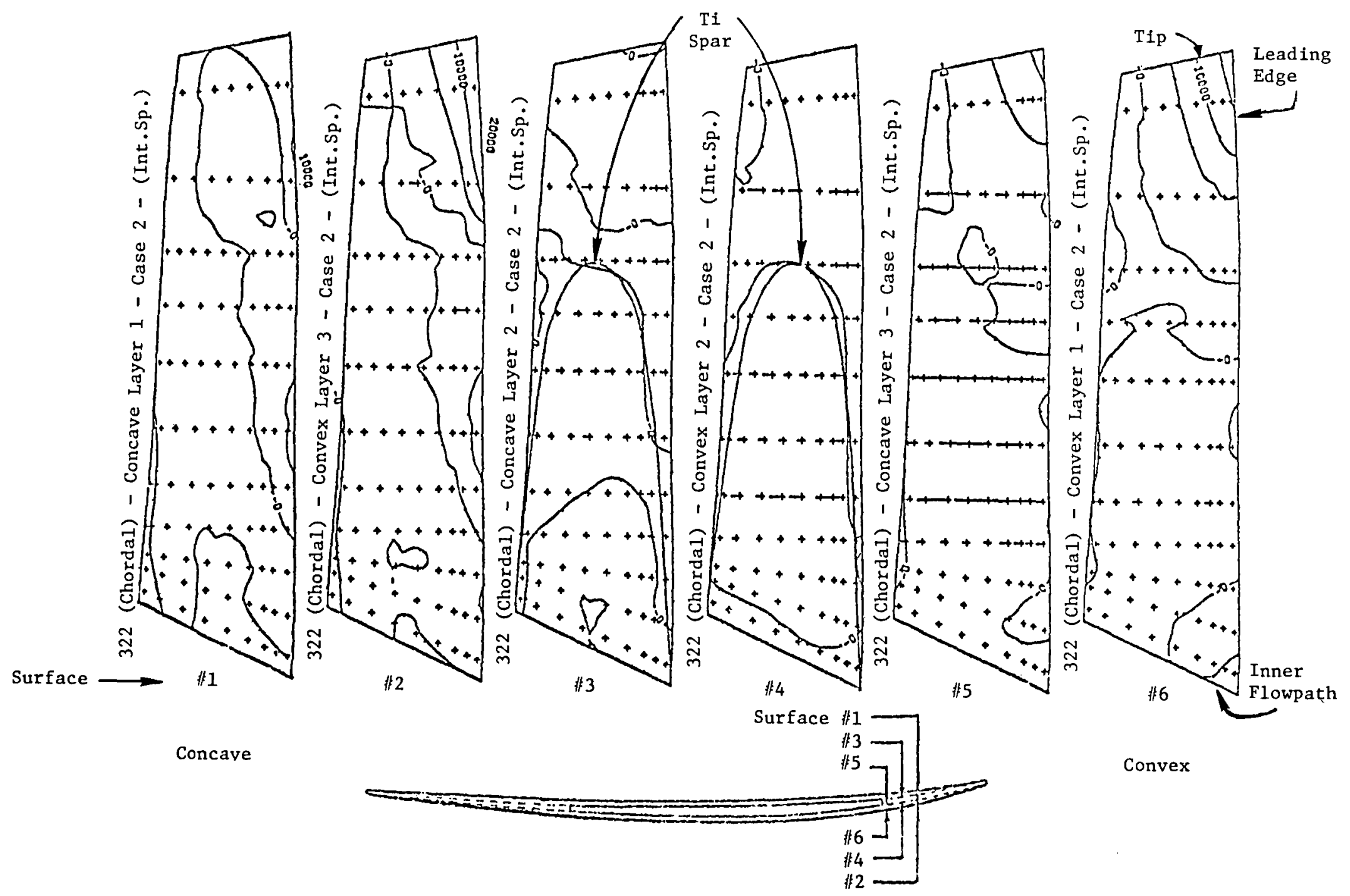

Figure 5. Internal Spar Blade (TiCore). Chordal Stress (psi), $4080 \mathrm{rpm}$. 


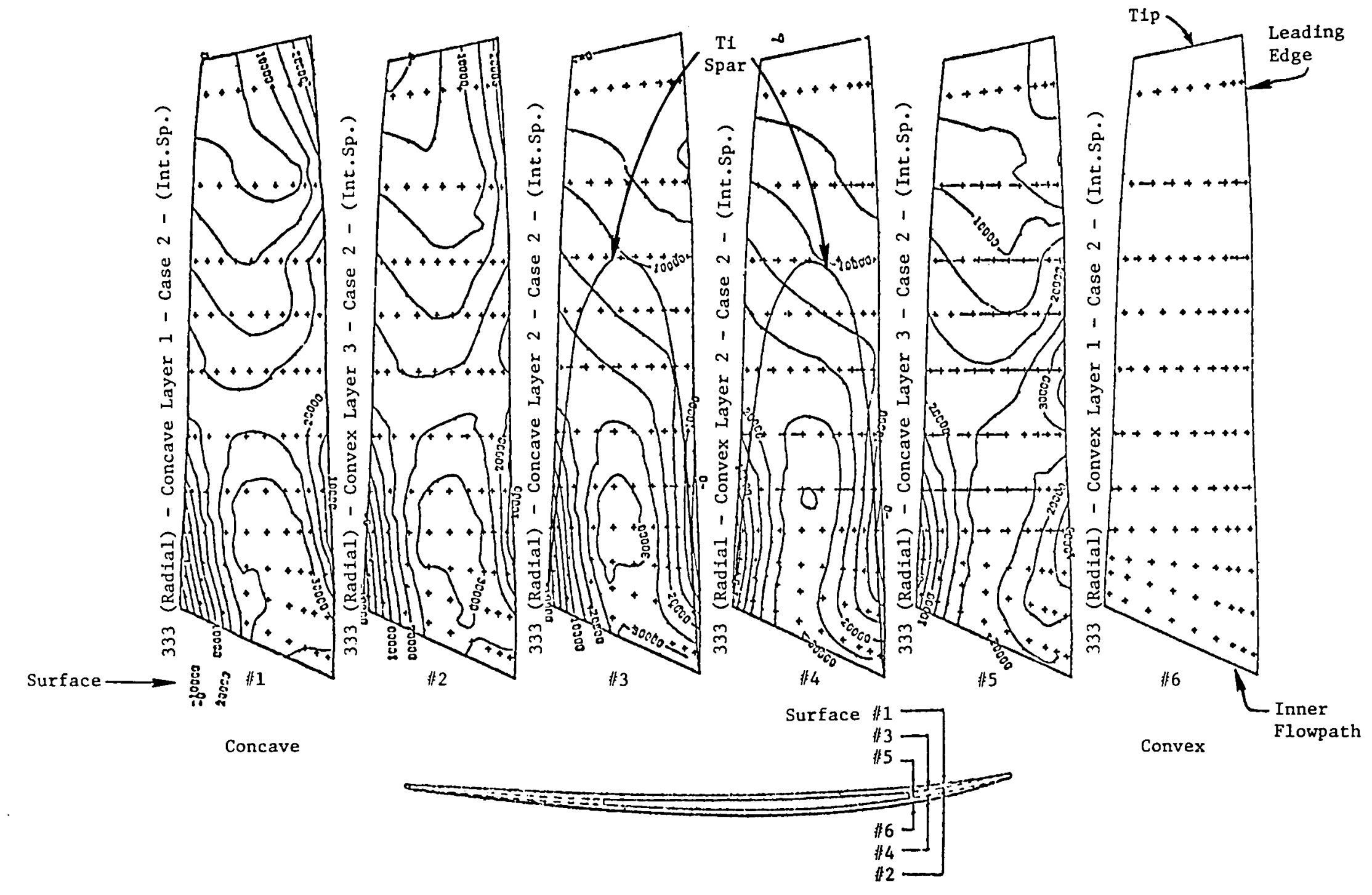

Figure 6. Internal Spar Blade (TiCore)Radial Stress(psi), $4080 \mathrm{rpm}$. 


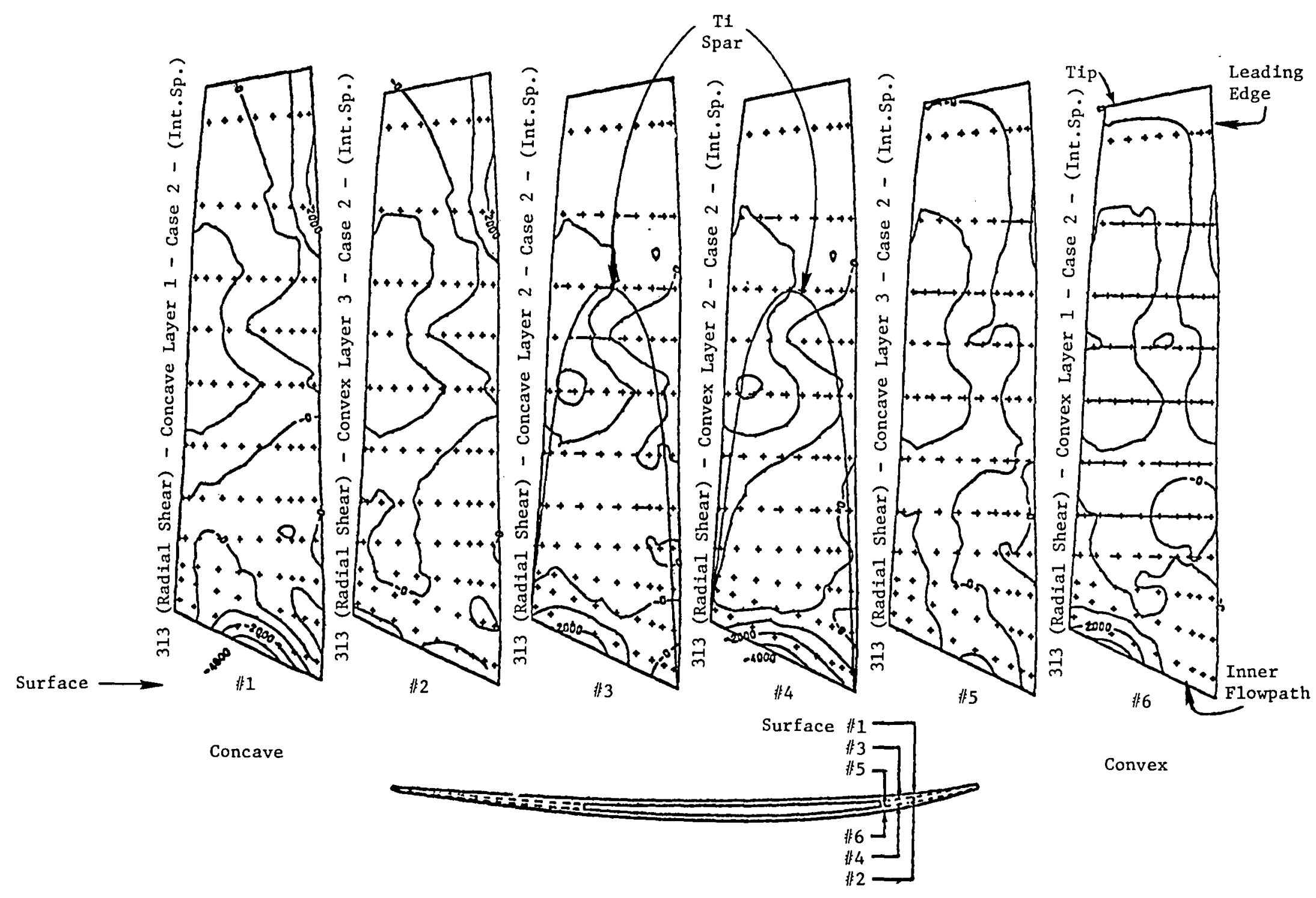

Figure 7. Internal Spar Blade(TiCore)Radial Shear Stress (psi), $4080 \mathrm{rpm}$. 


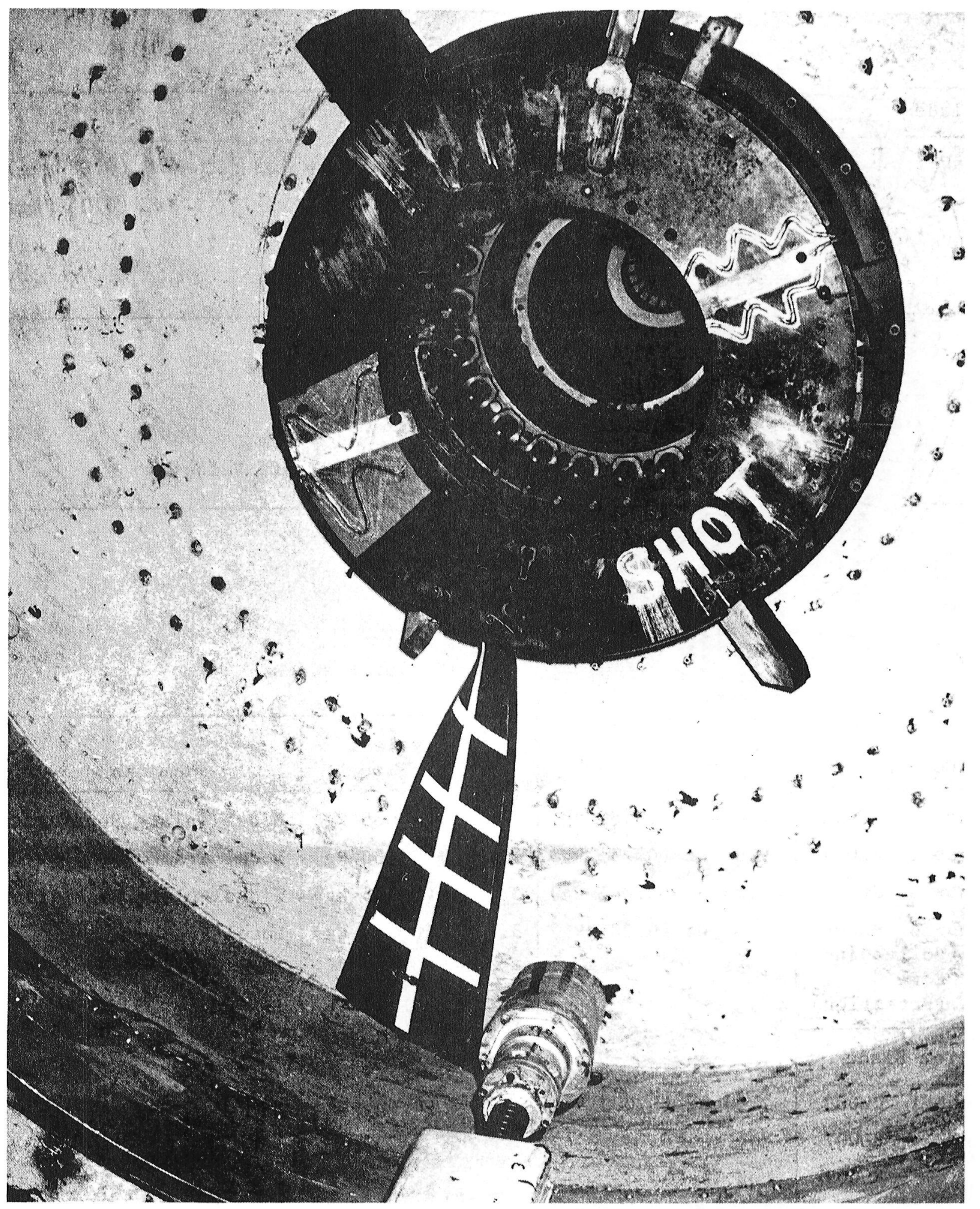

Figure 8. Superhybrid Blade Whirligig Impact Test Setup. 

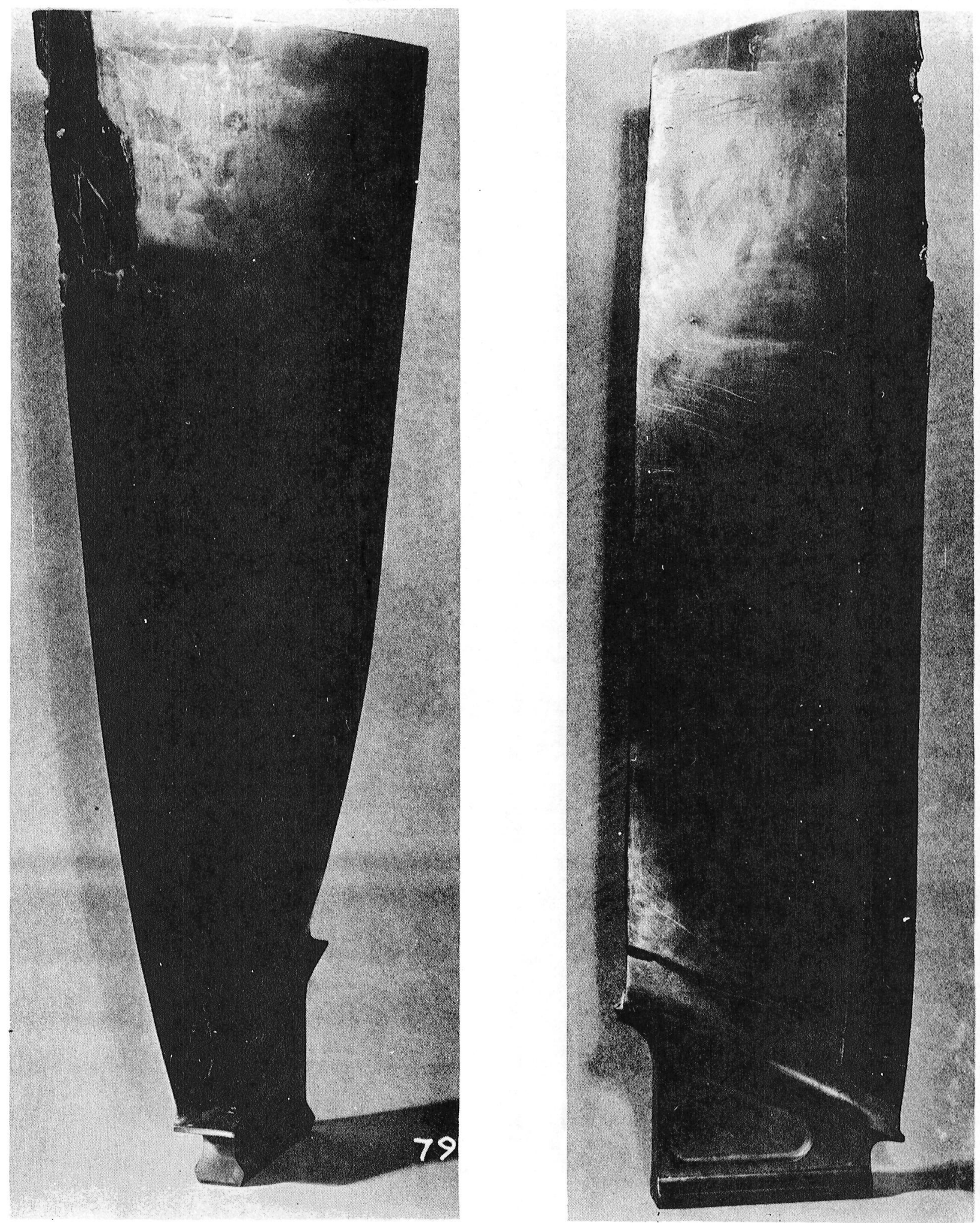

Figure 9. TiCore Superhybrid Blade 4 Without Leading Edge Protection Shown After Impact Testing of 3.0-Ounce Starling. 

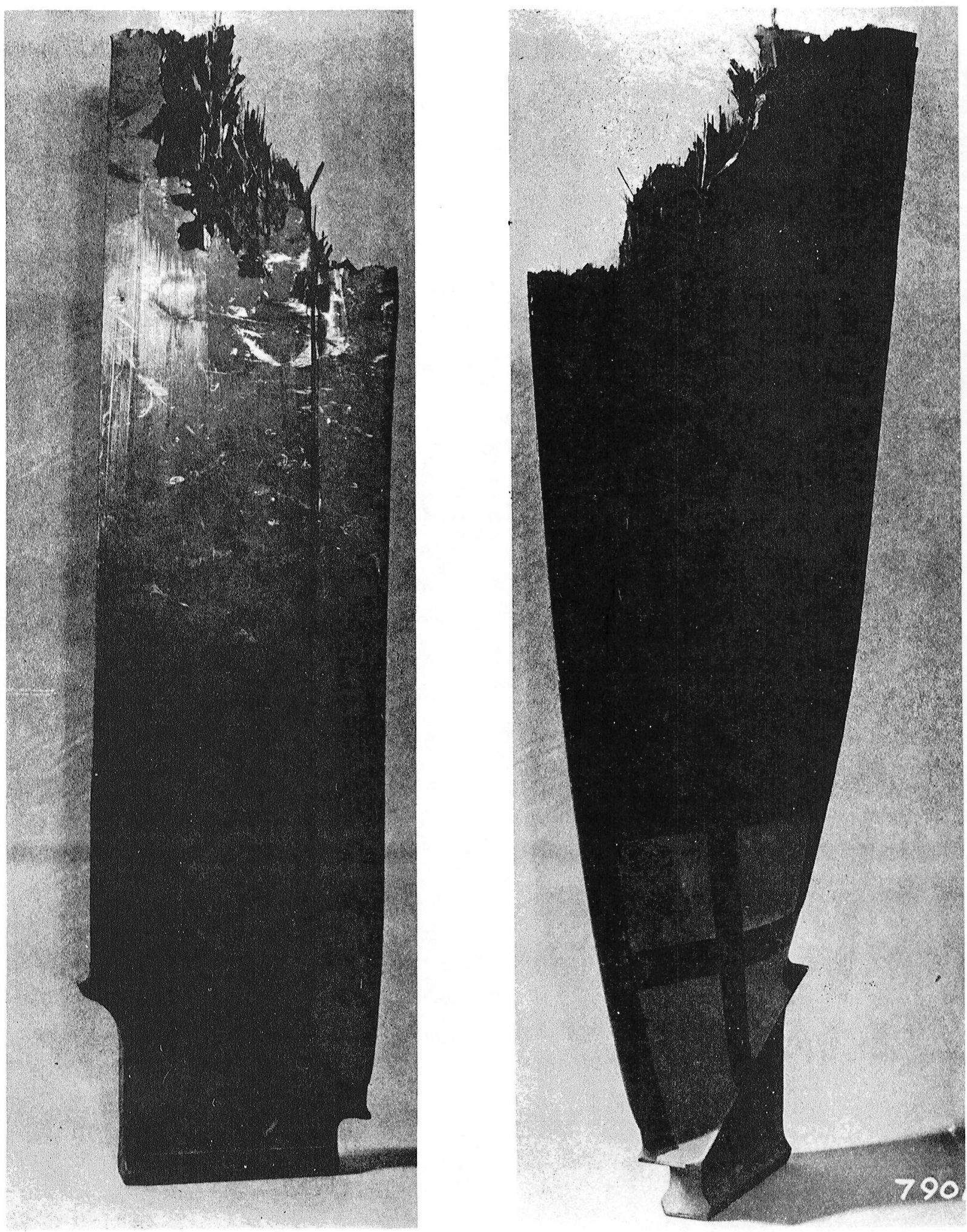

Figure 10. TiCore Superhybrid Blade 2 Shown After Whirligig Impact Testing of 1.5-pound Bird. 


\begin{tabular}{|c|c|c|c|c|}
\hline $\begin{array}{l}\text { 1. Report No. } \\
\text { NASA TM-81597 }\end{array}$ & \multicolumn{2}{|c|}{ 2. Government Accession No. } & \multicolumn{2}{|c|}{ 3. Recipient's Catalog No. } \\
\hline \multirow{2}{*}{\multicolumn{3}{|c|}{$\begin{array}{l}\text { 4. Title and Subtitle } \\
\text { SUPERHYBRID COMPOSITE BLADE IMPACT STUDIES }\end{array}$}} & \multicolumn{2}{|l|}{ 5. Report Date } \\
\hline & & & \multicolumn{2}{|c|}{ 6. Performing Organization Code } \\
\hline \multicolumn{3}{|c|}{$\begin{array}{l}\text { 7. Author(s) } \\
\text { C. C. Chamis, R. F. Lark, and J. H. Sinclair }\end{array}$} & \multicolumn{2}{|c|}{$\begin{array}{l}\text { 8. Performing Organization Report No. } \\
\text { E-580 }\end{array}$} \\
\hline \multicolumn{3}{|c|}{$\begin{array}{l}\text { 9. Performing Organization Name and Address } \\
\text { National Aeronautics and Space Administration }\end{array}$} & 10. Work Unit No. & \\
\hline \multicolumn{3}{|l|}{$\begin{array}{l}\text { Lewis Research Center } \\
\text { Cleveland, Ohio } 44135\end{array}$} & \multicolumn{2}{|c|}{ 11. Contract or Grant No. } \\
\hline \multirow{2}{*}{\multicolumn{3}{|c|}{$\begin{array}{l}\text { 12. Sponsoring Agency Name and Address } \\
\text { National Aeronautics and Space Administration } \\
\text { Washington, D.C. } 20546\end{array}$}} & \multicolumn{2}{|c|}{$\begin{array}{l}\text { 13. Type of Report and Period Covered } \\
\text { Technical Memorandum }\end{array}$} \\
\hline & & & \multicolumn{2}{|c|}{ 14. Sponsoring Agency Code } \\
\hline \multicolumn{5}{|c|}{$\begin{array}{l}\text { 15. Supplementary Notes } \\
\text { Prepared for the Twenty-sixth Annual International Gas Turbine Conference sponsored by the } \\
\text { American Society of Mechanical Engineers, Houston, Texas, March } 9-12,1981 \text {. }\end{array}$} \\
\hline \multicolumn{5}{|c|}{$\begin{array}{l}\text { 16. Abstract } \\
\text { An investigation was conducted to determine the feasibility of superhybrid composite blades for } \\
\text { meeting the mechanical design and impact resistance requirements of large fan blades for air- } \\
\text { craft turbine engine applications. Two design concepts were evaluated: (1) leading edge spar } \\
\text { (TiCom) and (2) center spar (TiCore), both with superhybrid composite shells. The investiga- } \\
\text { tion was both analytical and experimental. The results obtained show promise that superhybrid } \\
\text { composites can be used to make light-weight, high-quality, large fan blades with good structural } \\
\text { integrity. The blades tested successfully demonstrated their ability to meet steady-state } \\
\text { operating conditions, overspeed, and small bird impact requirements. }\end{array}$} \\
\hline \multicolumn{2}{|c|}{$\begin{array}{l}\text { 17. Key Words (Suggested by Author(s)) } \\
\text { Superhybrid; Boron/aluminum; Graphite- } \\
\text { fiber/resin; Finite-element analysis; } \\
\text { Vibration frequencies; Impact; FOD; } \\
\text { Fan blades; A ircraft engines; Stress } \\
\text { analysis; Bench tests; Composites }\end{array}$} & \multicolumn{3}{|c|}{$\begin{array}{l}\text { 18. Oistribution Statement } \\
\text { Unclassified - unlimited } \\
\text { STAR Category } 39\end{array}$} \\
\hline $\begin{array}{l}\text { 19. Security Classif. (of this report) } \\
\text { Unclassified }\end{array}$ & 20. Security $\mathrm{C}$ & $\begin{array}{l}\text { of this page) } \\
\text { assified }\end{array}$ & 21. No. of Pages & 22. Price \\
\hline
\end{tabular}

* For sale by the National Technical Information Service, Springfield, Virginia 22161 


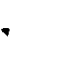


National Aeronautics and Space Administration
SPECIAL FOURTH CLASS MAIL BOOK
Washington, D.C.

20546

Official Business

Penalty for Private Use, $\$ 300$
Postage and Fees Paid National Aeronautics and Space Administration NASA-451

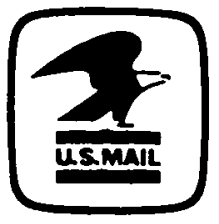

